som var en brydningstid, hvor der efterhånden kom et stigende antal akademisk uddannede læger ud i hele landet. Mariann Kristensen har undersøgt indholdet af Illustreret Børneblad for Nordslesvig fra 1890'erne, hvor der blev konstrueret en særlig dansk barndom som et ideal for de nordslesvigske børn. Marianne Brink Asvig Iversen har i sin artikel belyst et vigtigt kapitel i mange sydslesvigeres liv; nemlig deres oplevelser som feriebørn i Danmark.

God læselyst!

\section{Biskop Godske Ahlefeldt og altertavlen i Løjt Kirke}

- en førreformationshistorie

Af Jens BRUUN

Artiklen søger at give en forklaring på udformningen af billedprogrammet på en stor, kostbar fløjaltertavle, opsat i 1520, altså tre år efter at reformationsoprøret var begyndt med Martin Luthers 95 teser på kirkedøren i Wittenberg, og kun få år før reformationen så småt begyndte at røre på sig i Sønderjylland. Når Løjttavlen således sættes ind i sin dagsaktuelle sammenhæng, er der ét navn, der træder i forgrunden, Godske Ahlefeldt, den sidste katolske biskop over Slesvig Stift. Artiklen blev oprindeligt til på opfordring af afdøde biskop Niels Henrik Arendt, hvis minde den tilegnes.

Altertavlen i Løjt Kirke ${ }^{1}$ deler kår med stort set alle andre middelalderlige altertavler herhjemme, at det eneste 'dokument' om dens tilblivelse er selve dens eksistens. Og dog indeholder den en enkelt skriftlig kilde, nemlig den plattyske indskrift, som sidder på midtskabets nederste ramme, og som med indføjede mellemrum lyder: ANNO MCCCCCXX IN DEME IARE IS KARKHERE HAR IOHANN TAM DO WORT DIS TAFEL MAKET IN GO². Den oplyser altså, at tavlen er fra 1520, at Johan $\mathrm{Tam}^{3}$ da var sognets præst (kirkeherre), samt at den blev lavet $\mathrm{i}$, formentlig, Guds navn. Vil man dybere ind i, hvad tavlen rummer af budskab(er), må det ske ved omhyggelig betragtning og analyse af dens billedverden, dens figurer og malerier

At bestille en altertavle som den i Løjt Kirke var ingen lille eller enkel sag, der var talrige forhold at gennemtænke, tage stilling til og planlægge; en altertavle var ingen hyldevare ${ }^{4}$. Grundlæggende skulle tavlens størrelse i forhold til kirkens nyligt overhvælvede kor, hvor den skulle opstilles, fastlægges, forholdet mellem højde og bredde og de forskellige dybder besluttes, dens bærende konstruktioner, træets art og kvalitet afgøres, klargøringen af de synlige flader til bemaling eller baggrundsudsmykning bestemmes. Og ikke mindst skulle den sindrige indretning af tavlens tre forskellige stande udtænkes; første stand eller feststanden med den udskårne Golgatascene var formentlig kun tænkt synlig ved kirkeårets store fester; anden stand, fastestanden med 
de store malerier fra Kristi lidelseshistorie var til brug i den 40 dage lange fastetid inden påske; tredje stand, hverdagsstanden, var den, der til enhver tid skulle minde beskueren om troens grundforhold, ikke mindst i en opbrudstid. Det skulle nærmere besluttes, hvordan alt det synlige, billedprogrammet, i detaljer skulle udformes; hvilke personer og begivenheder skulle afbildes, i hvilken stilart og efter hvilke forlæg skulle de udføres, hvilke helgener skulle udvælges og hvor på tavlens skulle de optræde?

Der skulle findes et værksted eller en mester, der kunne opfylde alle de opstillede krav og ønsker. Endelig skulle man da også have en pris, en vigtig ting for løjtinge og andre involverede $\mathrm{i}$ begyndelsen af 1500-tallet, og i forlængelse heraf: hvem skulle betale?

Og bag det hele: hvem skulle beslutte, hvilke interesser skulle tilgodeses, i hvilke forsamlinger har der været diskuteret, har løjtingene været repræsenteret, er sognepræsten Johan Tams navn på daterings-

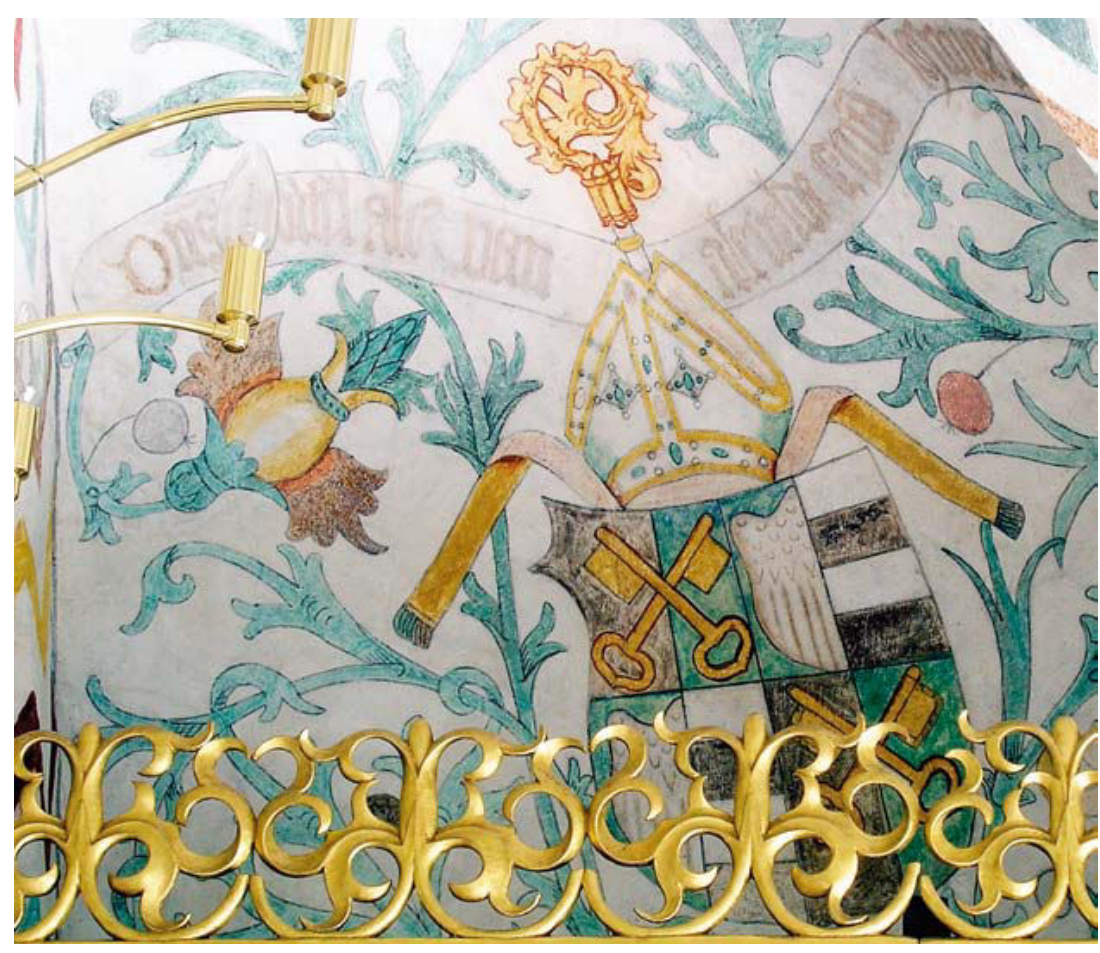

Våbenskjold fotograferet efter istandsættelsen af kalkmalerierne i 1995. indskriften udtryk for, at han har spillet en afgørende rolle, eller er beslutningerne blevet taget højere oppe i det kirkelige hierarki, evt. med støtte fra altertavlekyndige fagfolk? Man gad nok have været en flue på væggen under alle disse forhandlinger frem til kontraktslutningen. For som nævnt har intet dokument i sagen overlevet de forløbne fem århundreder.

Hvad jeg her vil søge at afdække, er, hvilken rolle biskop Ahlefeldt kan have spillet i tavlens tilblivelse.

På en af hvælvkapperne bag altertavlen i Løjt Kirke ses et kalkmalet våbenskjold med en biskops stav og hue med bånd samt en udvisket og næsten ulæselig indskrift. I 1776 aftegnede kongelig arkivtegner Søren Abildgaard våbenskjoldet og tydede indskriftbåndets tekst ${ }^{5}$. Med forkortelserne opløst og på nudansk står der: "Hr. Gotschalk van Ahlefeldt, slesvigernes biskop". Våbenskjoldet er sammensat af Ahlefeldternes våben ${ }^{6}$ med svanevingen og de fire bjælker samt bispeembedets korslagte Peters-nøgler. Gotschalk, eller Godske som han oftest kaldes, Ahlefeldt var den sidste katolske biskop over Slesvig Stift, som Løjt Sogn dengang hørte under; han blev indsat i 1507 og bestred embedet indtil sin død i 1541.

Men hvad i alverden laver biskoppens våbenskjold, så markant placeret, i Løjt Kirke? Med al sandsynlighed er det et stiftermærke ${ }^{7}$, der angiver, at det var Godske Ahlefeldt, der tog initiativ til kirkens nye altertavle, øvede afgørende indflydelse på dens billedprogram samt formentlig sørgede for finansieringen af den meget, meget kostbare tavle. Gennem en nærlæsning af tavlens ikonografi vil jeg som anført søge at påvise, på hvilke felter og med hvilket sigte Ahlefeldts indflydelse har gjort sig gældende.

\section{Biskop Ahlefeldt}

Men først et par ord om manden. Godske Ahlefeldt (o. 1475-1541) var ud af en af senmiddelalderens betydeligste og mest velhavende adels-

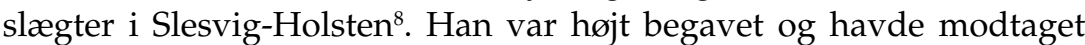
tidens højeste uddannelse med teologiske studier ved universitetet i Rostock og en juridisk doktorgrad fra universitetet i Bologna. Han gjorde en smuk gejstlig karriere, såvel ved kurien i Rom som i Slesvig Stift, hvor han som sagt i 1507 valgtes til biskop. Verdsligt virkede han en årrække som hertugens kansler og udførte desuden flere betroede diplomatiske opgaver for kongen?. 
Godske Ahlefeldt på titelbladet af Slesvig-breviaret. (Det Kgl. Bibliotek).

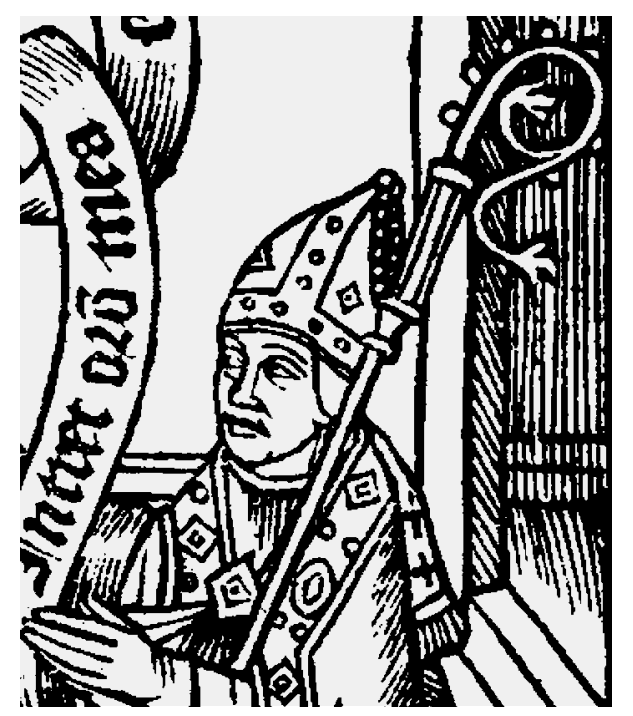

Godske Ahlefeldt var som biskop bevidst om, at kirken, dvs. den romersk-katolske kirke, var i voksende problemer. Nye tanker spirede frem, som anfægtede kirkens autoritet, og kritiske røster angreb med stigende styrke kirkens forvaltning af sin opgave i kristentroens tjeneste. Kritikken fandt som bekendt sit mest markante udtryk i Martin Luthers opgør med kirken, åndeligt som materielt, der begyndte i oktober 1517 med de 95 teser mod især kirkens afladspraksis. Besked om teserne med deres potentielt farlige indhold blev naturligvis spredt om ikke med lynets, så med hestens fart ad kirkens velfungerende kommunikationslinjer til i hvert fald alle biskopper i kirkens vidtstrakte administration. Det samme gjaldt selvfølgelig for Luthers senere, trykte skrifter.

Men i 1517 havde biskop Ahlefeldt allerede i en årrække virket for at styrke kirkens organisation og åndelige indhold i sit ansvarsområde, Slesvig Stift. Han havde sørget for at få orden på stiftets besiddelser og økonomi, og ikke mindst var han virksom for en mere ensartet gudstjeneste i sit stift. Til det formål fik han i Paris i 1512-13 trykt hele tre liturgiske bøger: en alterbog, et breviar med kalendarium, dvs. en oversigt over kirkeårets fejringer ${ }^{10}$, samt en bønnebog til præstens daglige brug.

Han var derfor rede til at kaste sig ud i en kamp for, at de nye tanker kunne blive til ny inspiration og fornyelse inden for kirken og ikke til et kirkebrud. En kamp som ikke alene skulle vindes blandt gejstligheden, men i mindst lige så høj grad skulle vindes rundt i sognemenighederne. Her kunne en pragtfuld, righoldig og velgennemtænkt altertavle sikkert vinde gehør blandt gejstlige som lægfolk.

\section{Altertavlens hverdagsstand}

Når man i dag besøger Løjt Kirke, oplever man sædvanligvis kun altertavlens første stand, feststanden, der er opbygget med en Figurrig Golgatascene og to værnehelgener i midtskabet samt tolv apostelfigurer i fløjene, alt i stærke farver og med rig forgyldning ${ }^{11}$.

Ikke desto mindre vil jeg i denne analyse af Løjttavlen tage udgangspunkt i tavlens tredje stand, hverdagsstanden; den er ikke længere i gudstjenestelig brug. Men så vidt vi ved, har det i senmiddelalderen været den, kirkegængerne oftest så (se side 13).

Man kan indledningsvis undre sig over, at hverdagsstanden på en kristen altertavle kun har Kristus afbildet i Anna Selvtredje-gruppen i predellaen, altertavlens fodstykker - som et lille barn hos sin mor, Jomfru Maria, og mormor, legendens S. Anna. Men måske netop derfor er predellaen udformet, så den som en trefløjet tavle i sig selv afspejler altertavlens første og tredje stand med de store dramatiske scener i midtfeltet og apostle eller helgener i fløjene. Helgenerne på predellaens to 'fløje' er malet ganske som dem på tredjestandens fløje. Men

Måske en Godske Ahlefeldt afbildet som S. Erasmus på Løjttavlen? Portrætligheden strækker sig dog næppe ud over det mulige.

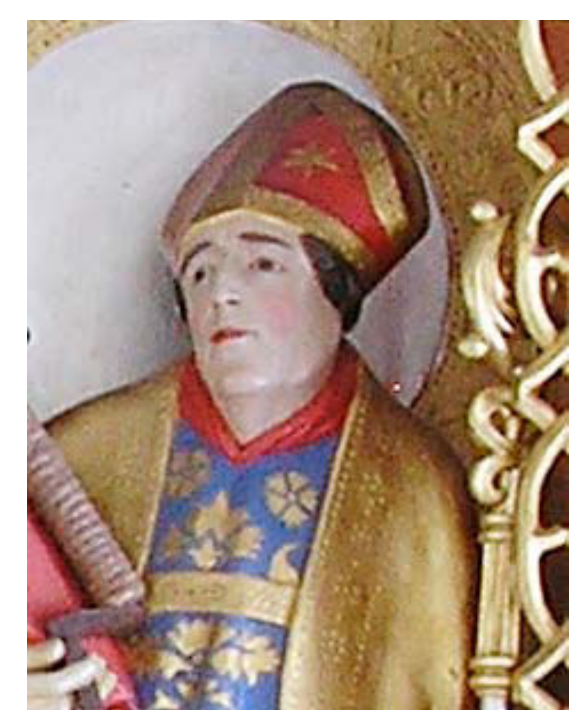


det budskab, som de store malerier på hverdagsstandens midtfelt og fløje vil formidle, må altså være så vigtigt, at det kan forvise et egentligt Kristus-motiv til den langt mindre iøjnefaldende predella. Ikke desto mindre kan man i 1521 henvise til "S. Annæ alter" i Løjt ${ }^{12}$, hvormed der må menes kirkens nye altertavle.

Og predellaen er i sig selv betydningsladet. Den meget yndede Anna Selvtredje-gruppe bringer os helt tilbage til syndefaldet i Edens Have; Maria rækker et æble frem - den frugt netop, som Eva bragtes til fald ved - men som Jesusbarnet nu lægger sin hånd velsignende på. Også fløjenes helgener ${ }^{13}$, de to biskopper yderst og de to kvinder inderst, må være valgt med omhu, selvom vi i dag ikke ganske kan gennemskue motivet. Det giver god mening at følge den formodning, at den første biskop er S. Ansgar, Danmarks og Nordens apostel, ligesom den nonneklædte kvinde, stående ved en kirkebygning, må være S. Birgitta af Vadstena, hvis Himmelske Åbenbaringer er afspejlet på tavlens første stand. Det er derimod endnu ikke lykkedes at finde en helt fyldestgørende forklaring på valget af S. Apollonia og biskoppen S. Dionysius i Løjttavlens sammenhæng. Nærliggende er det dog at se de to martyrer som spejlinger af de gejstlige og kvindelige helgener/martyrer på selve tavlen lige ovenover.

Nu til nærlæsningen af Løjttavlens hverdagsstand. Den er som nævnt i princippet opbygget ganske som første stand, feststanden, med dramatiske scener i midtskabet og tolv personer i fløjene.

I stram komposition viser fløjene tre gange fire af den katolske kirkes fremmeste skikkelser; de er gengivet stående og med et minimum af bevægelse; hvem de er, fremgår af de attributter, de står med eller ved. Lyset kaster urealistisk små, trekantede skygger, der blot skal angive lysets retning fra venstre.

Inderst i de fire felter ses personer, der har haft afgørende indflydelse på kristendommens praksis: Nederst til venstre ses Maria Magdalene, 'apostlenes apostel'; hun står med krukken med den olie, hvormed hun salvede Kristus. Over hende står S. Antonius, der ved at drage ud i ørkenen for i ensomhed at søge Gud - og dér måtte overvinde svære tvivl og fristelser - blev til inspiration for den kristne tradition for den lyttende, frugtbare stilhed; han står med det T-formede Antonius-kors i højre hånd og et svin ved sin side. Øverst til højre står S. Benedikt, der med sin regel: Bed og arbejd, fik reformeret og fornyet klosterlivet; staven, han holder sammen med bogen, er her blevet til en bispestav. Under ham står S. Laurentius med den rist, hvorpå han brændtes til døde;

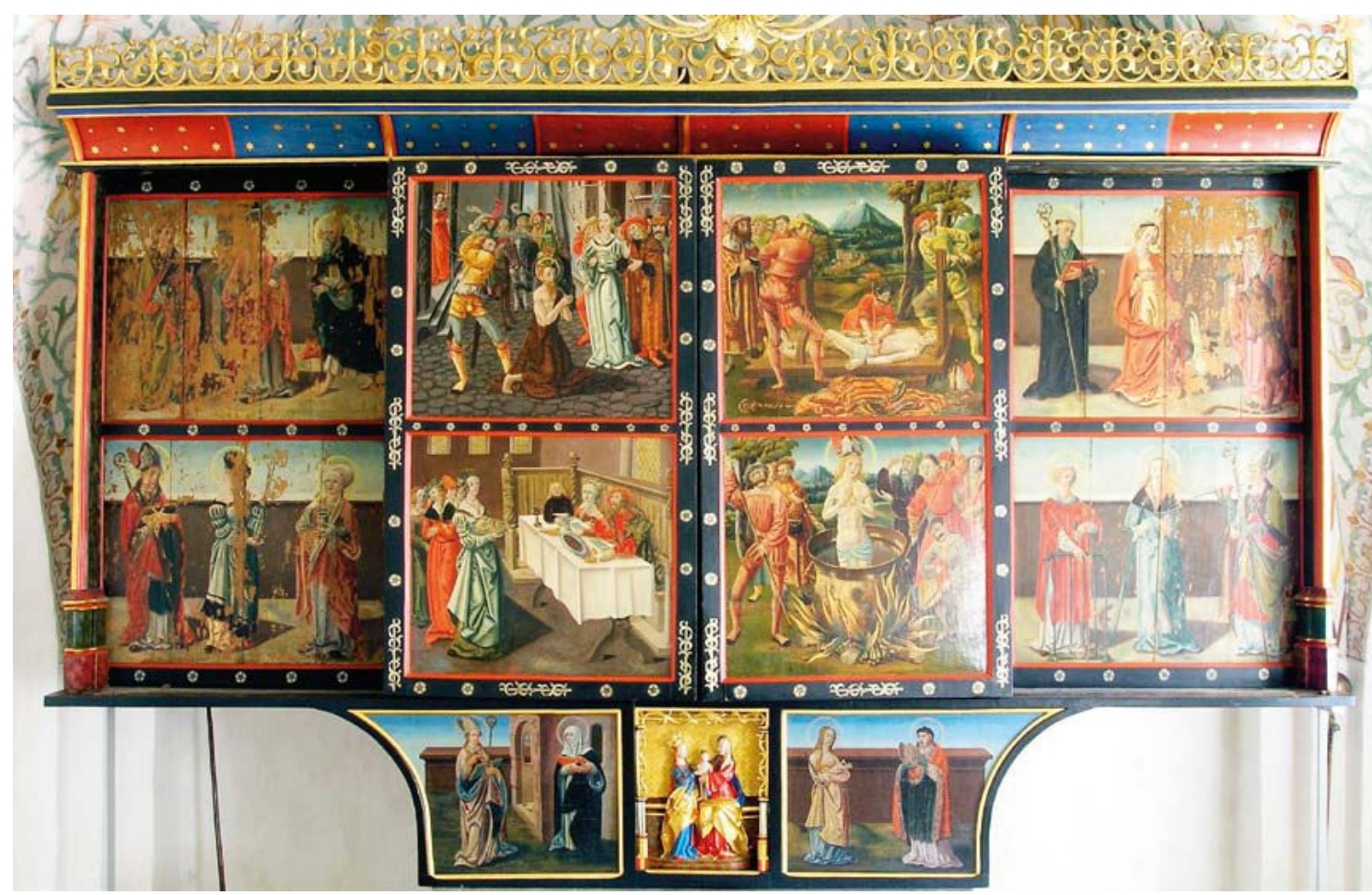

I denne tredje stand formodes det, at Løjttavlen har stået uden for de kirkelige højtider.

han kæmpede for kirkens uafhængighed af de verdslige magthavere, og har derfor altid, men ikke mindst i kirkens daværende situation, være vigtig at holde for øje.

Yderst i felterne står fire af kirkens største teologer: S. Ambrosius, pave Gregor den Store, S. Hieronymus og S. Augustin. I 1295 ophøjedes disse fire til kirkelærere, hvilket indebærer, at deres skrifter og bibelfortolkninger er autoritative og bindende for kirken. Kronologisk er Ambrosius (339-397) den tidligste; han var en stor prædikant, der indførte 'den ambrosianske vekselsang' i gudstjenesten; som biskop i Milano hævdede han kirkens selvstændighed over for magthaverne. Næst i tidsfølgen står Hieronymus (o. 345-420), hvis vigtigste og blivende indsats er hans oversættelse af Bibelen fra grundsprogene hebraisk og græsk til latin; oversættelsen, kaldet Vulgata, 'den almindelige', er i princippet stadig den katolske kirkebibel. Dernæst Augustin (354-430), den mest indflydelsesrige, såvel teologisk som kulturelt, af de latinske 
kirkefædre. Og endelig pave Gregor den Store (o. 540-604), den første af middelalderens store paver; hans navn er især knyttet til den katolske messe, som under hans indflydelse fik sin faste form.

Disse otte af kirkens allerstørste skikkelser vender sig parvist mod de fire kvinder i midten. Skønt de mest er at ligne ved romanfigurer og ikke har rod i virkeligheden, repræsenterer disse kvinder kristelige dyder som afholdenhed og udholdenhed. Fælles for dem er, at de dels ikke ville afsværge deres kristentro, dels ville beholde deres jomfruelige renhed og derfor nægtede at indtræde i ægtestanden; de måtte alle udstå svære lidelser, inden de led martyrdøden. Ud fra deres attributter kan de, med uret, navngives S. Ursula med pil, S. Barbara med tårn, S. Margaretha med drage og S. Katharina med sværd og marterhjul; tilsammen udgør de en variant af De fire Hovedjomfruer ${ }^{14}$. Sædvanligvis tælles S. Dorothea som en af de fire, men hun er her erstattet af S. Ur-

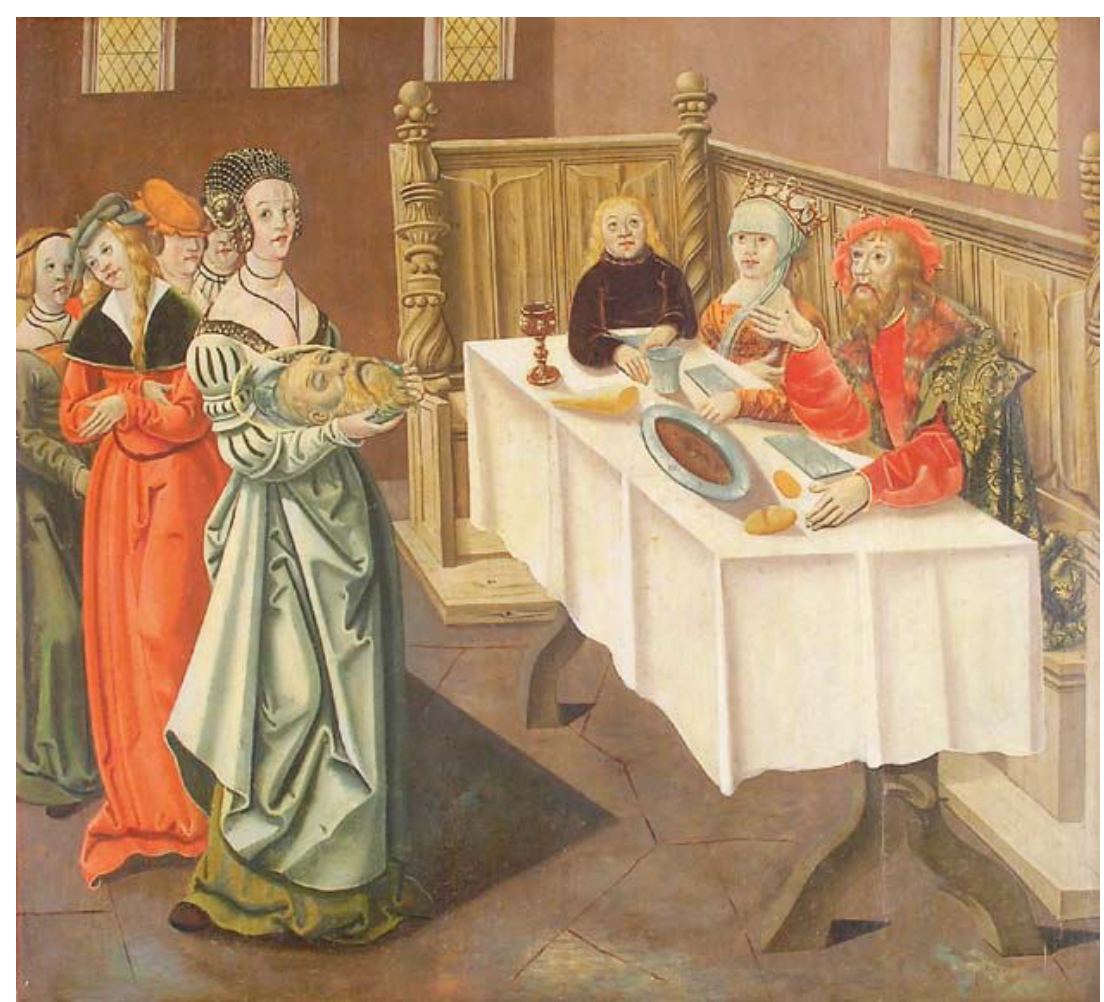

Salome frembærer Johannes Døbers hoved på et fad ved kong Herodes' fødselsdagsfest. sula; heri kan man se et tydeligt aftryk af Godske Ahlefeldt, der netop indførte Ursulas kult i sit stift, som det fremgår af Slesvig-breviaret fra 1512. Hvorfor Ursula, der ifølge legenden sammen med sit følge af 11.000 jomfruer, blev dræbt af hunnerkongen Attila, spiller en særlig rolle her, må jeg afstå fra at give en forklaring på.

I alt viser fløjene en imponerende, men statisk og bagudskuende, sammenfatning af den katolske kirkes tradition, lærdom og styrke ved slutningen af middelalderen i Danmark.

\section{Fra middelalder til renæssance}

Det er derfor for en eftertid ejendommeligt at se, hvordan malerierne i midten næsten bogstaveligt sprænger sig vej ud i en ny og genfødt verden. Ikke hvad motiverne angår, de er en udfoldelse af budskabet fra fløjene om de omkostninger, som kristentroen kan have. De to malerier til venstre er bibelske og fortæller om Johannes Døbers endeligt ved halshugning ${ }^{15}$; til højre får vi to scener fra legendens fortælling om S. Erasmus' lidelser og død ${ }^{16}$. Nej, det nye er måden, det bliver fortalt på, den fortællerglæde, der lyser ud af gengivelsen af selv de mest forfærdende begivenheder.

Vi ser her et af den italienske renæssancekunsts tidligste indtog i den danske kunsthistorie, $i$ form af malerier på en sengotisk altertavle. Den unge Godske Ahlefeldt havde opholdt sig i Italien netop i disse kunsthistorisk så vigtige år, da 'genfødelsens kunst' brød igennem også internationalt ${ }^{17}$, og han kan ikke have undgået at blive dybt påvirket af den. Ved at sørge for, at Løjttavlens malerier blev skabt af en eller flere malere, der var oplært i de nyeste kunstneriske principper, kunne han demonstrere sin åbenhed over for det nye og fornyende, i kunst som i kirke. Malerierne er gennemtrængt af renæssancens vigtigste landvindinger: interessen for arkitekturen, herunder den klassiske, og sansen for landskabet, begge dele gengivet med stor nøjagtighed ved hjælp af det nyopfundne centralperspektiv, samt det omhyggelige studium af menneskelegemet, så det kan gengives naturtro i alle dets stillinger.

Stedet er ikke her til at analysere samtlige tavlens renæssancemalerier, der ud over de fire her på tredje stand rummer otte på anden stand. Jeg vil blot samle opmærksomheden om det nederste af malerierne af Johannes Døbers martyrdød.

Vi er trådt ind i kong Herodes' palads. Interiøret, der viser møblementet $i$ et fornemt miljø i begyndelsen af 1500-tallet, er tegnet med et 


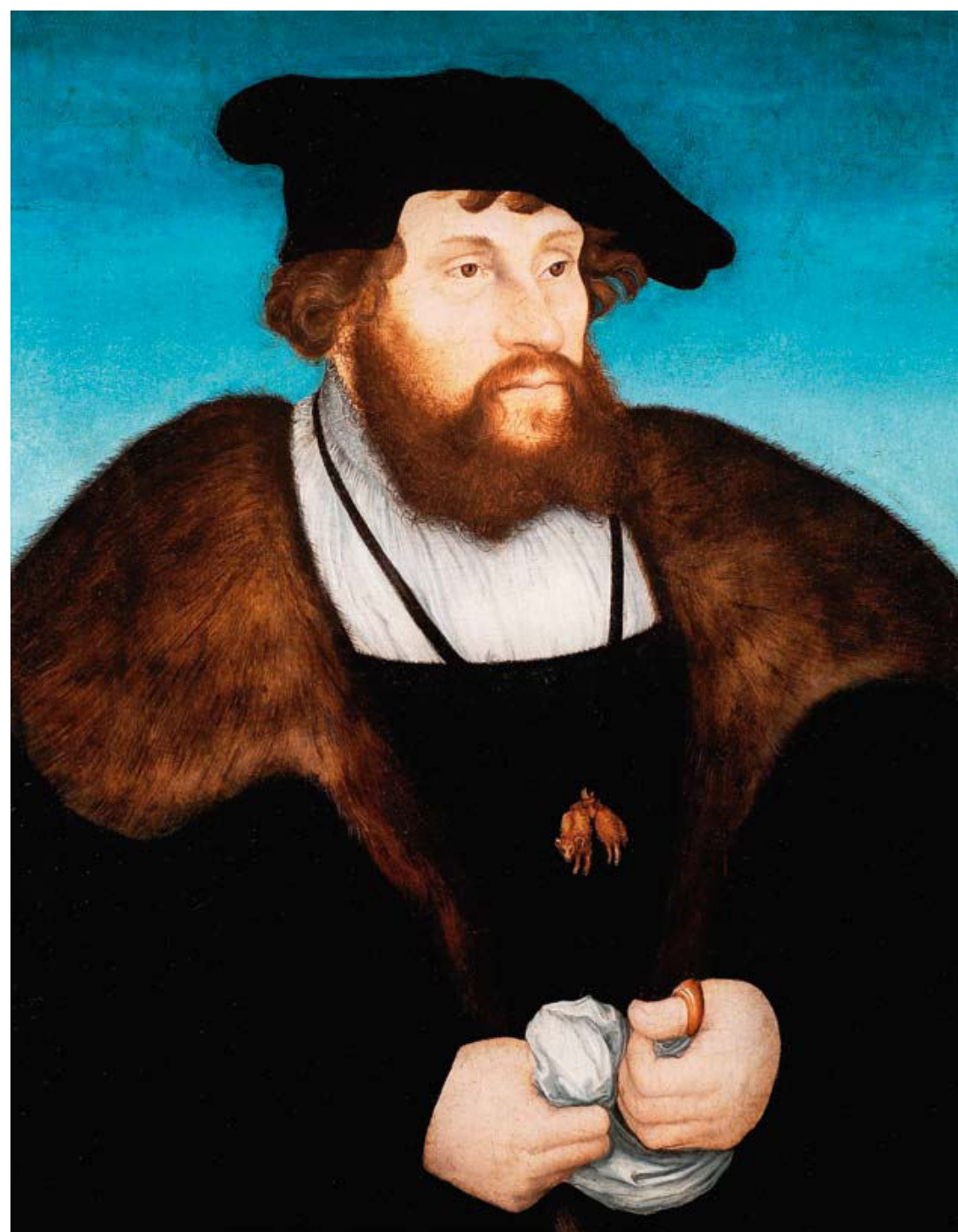

Christian II, maleri af Lucas Cranach den Ældre 1523. Museum Sønderjylland.

knap færdigtilegnet centralperspektiv. Salome bærer Johannes Døbers afhuggede hoved frem på et fad til højbordet, hvor kongen sidder med sin dronning, Herodias, og en af deres gæster. De sidder på en bænk, der står på en forhøjning, skærmet af panelvægge med fantasifuldt udførte hjørnesøjler. Meget bemærkelsesværdigt er det, at maleren har

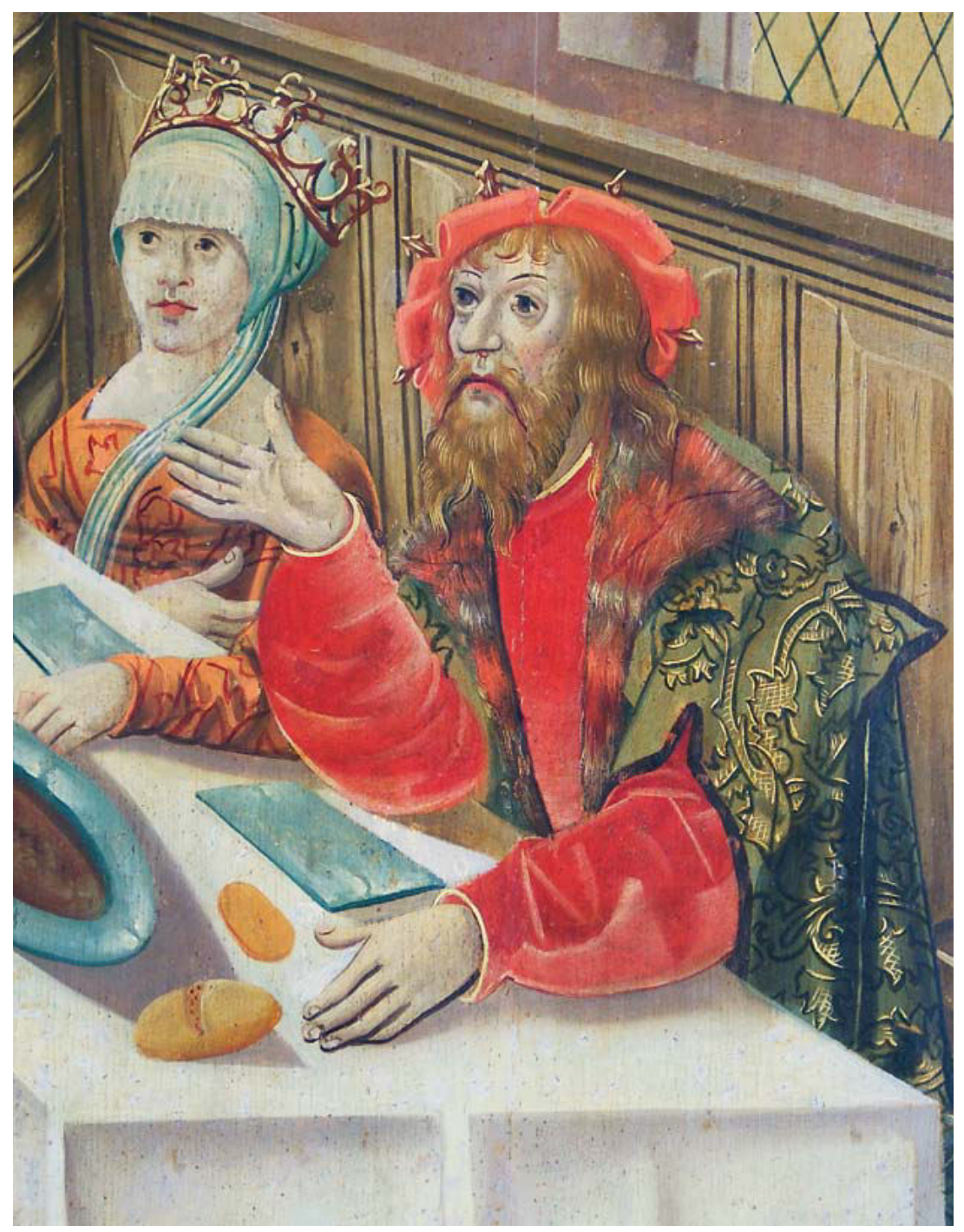

Sandsynligt portræt af Christian II i rollen som kong Herodes, maleri på Løjttavlen 1520.

lagt Herodes' portræt tæt op ad kong Christian II ${ }^{18}$, der fra 1513 til 1523 både var konge af Danmark og medhertug over Slesvig-Holsten.

Hvem, må man spørge, har haft årsag og mod til at slynge en sådan majestætsfornærmelse i ansigtet på konge og hertug Christian, at fremstille ham i skikkelse af en af Bibelens værste tyranner? Det er uden 
tvivl sket efter besked fra altertavlens bestiller, og det udgør formentlig det tungest vejende indicium for, at bestilleren er Slesvigs biskop, Godske Ahlefeldt. Fra sine missioner for kongen kendte han ham som en stærk renæssancefyrste, der hensynsløst stræbte mod en kongemagt, som herskede over såvel adel som kirke. I den magtkamp så kongen sin fordel i, at reformationsoprøret førte til en splittelse af kirken i nationale enheder, der jo lettere lod sig beherske. Med blik også for den åndelige kamp foranledigede han den første oversættelse af Det Nye Testamente til dansk (den udkom i Wittenberg i 1524).

I denne magtkamp ønskede Godske Ahlefeldt at kaste sit lod, og med sin slægtsmæssige baggrund behøvede han ikke at lægge bånd på sit udtryk, han havde intet at frygte. Som sagt sad han da også, temmelig uanfægtet af reformationen, i sit embede helt frem til sin død i 1541.

\section{Altertavlens feststand}

$\mathrm{Nu}$ handler denne artikel primært om de aftryk, som Godske Ahlefeldt kan have sat på alterudsmykningen i Løjt Kirke, og de findes især på tavlens tredje stand. Derfor er dens første og anden stand indtil nu kun nævnt perifert, men det skal der her rådes bod på med en analyse af forbindelsen mellem tredje og første stand. For uanset hverdagsstandens fortællinger fra kristendommens dramatiske historie, så er det første stand, feststanden, der sammen med anden stand, er udgangspunktet med beretningen om kristendommens fødsel.

De to stande er som nævnt opbygget helt parallelt: i midterfeltet dramatiske optrin og i fløjene tolv vidner. Vidnerne på tredje stand hører alle til i de første århundreder af kirkens historie, mens de tolv på første stands fløje er Jesu samtidige, nemlig de apostle, som han selv havde udvalgt. Deres individuelle skæbner efter Jesu død på korset er antydet gennem de attributter, de står med.

Opbygningen af tavlens første stand, en Figurrig Golgatascene flankeret af tolv apostle, er den hyppigst anvendte komposition i de danske middelaldertavler, man genfinder den i omkring hundrede tavler. Ikke desto mindre bliver det ved en sammenligning klart, at Løjttavlen adskiller sig markant fra så at sige alle de andre lignende. Man fornemmer hele vejen igennem en høj teologisk og kunstnerisk bevidsthed. Den nøjere beskrivelse og analyse af Golgatascenen og dens tætte forbindelse til de otte malerier på anden stand, med yderligere motiver fra lidelseshistorien, hører dog ikke hjemme i denne sammenhæng; jeg vil alene koncentrere mig om de to værnehelgener.

I en kristen, kirkelig sammenhæng fortæller valget af Johannes Døber som værnehelgen om kirkens grundlæggende hverv, at forkynde Jesus som Kristus. Johannes er netop afbildet med den løftede højre hånd, der peger på Guds Lam, der ligger på bogen i hans venstre. Under hans stjernestrøede helgenkappe ses hans kamelskindsklædning fra tiden, da han forkyndte og døbte i ørkenen ved Jordanfloden. Han er den kristne kirkes første og grundlæggende vidne med sit udsagn om Jesus: "Se, dér er Guds lam, som bærer verdens synd"19. Men videre peger hans finger ind mod Golgatascenen, der beretter om de omkostninger, der skal følge af at bære 'verdens synd'.

Tavlens anden værnehelgen er S. Erasmus, der står på den anden side af Golgatascenen. Han er iklædt fuldt bispeskrud, og hans dalmatika er smykket i blåt og guld ligesom foret på Johannes Døbers helgenkappe, et tegn på hans helgenværdighed. Endnu har vi ikke fået en forklaring på den vinde, han holder sammen med bogen; den forklaring får vi på tredje stand. Som billedmæssig fortsættelse af Golgatascenens gru står S. Erasmus som repræsentant for den kirke, der skabtes på grundlag af troen på Jesus som Guds lam, hans død og opstandelse. Erasmus repræsenterer den sejrende kirke, ecclesia triumphans.

\section{Altertavlens dobbelte formål}

Altertavlen skulle jo løse to store opgaver. Den ene var at smykke kirken og fryde og opbygge menigheden i Løjt; men samtidig skulle den for den indviede være et klart indlæg $i$ den teologiske og kirkelige debat.

Altertavlens første og anden stand, feststanden og fastestanden, fortæller som sagt i prægtige og dramatiske relieffer og malerier Kristi lidelseshistorie fra Indstiftelsen af Nadveren skærtorsdag til Kristi Opstandelse påskemorgen. Dens forkyndelse bliver sammenfattet af en kvinde, der knæler forrest i midten af feststanden ${ }^{20}$. Hun vender sig mod enhver tids beskuer og synes at sige: Når nu Kristus i sin kærlighed til ethvert menneske, dig ikke undtaget, har gennemlidt alle disse provelser og lidelser, hoad er da dit gensvar?

Kirkens gensvar formulerede Godske Ahlefeldt da, som vi har set, på altertavlens tredje stand, hverdagsstanden. Første og tredje stand bindes yderligere sammen ved, at tavlens værnehelgener, Johannes Døber 


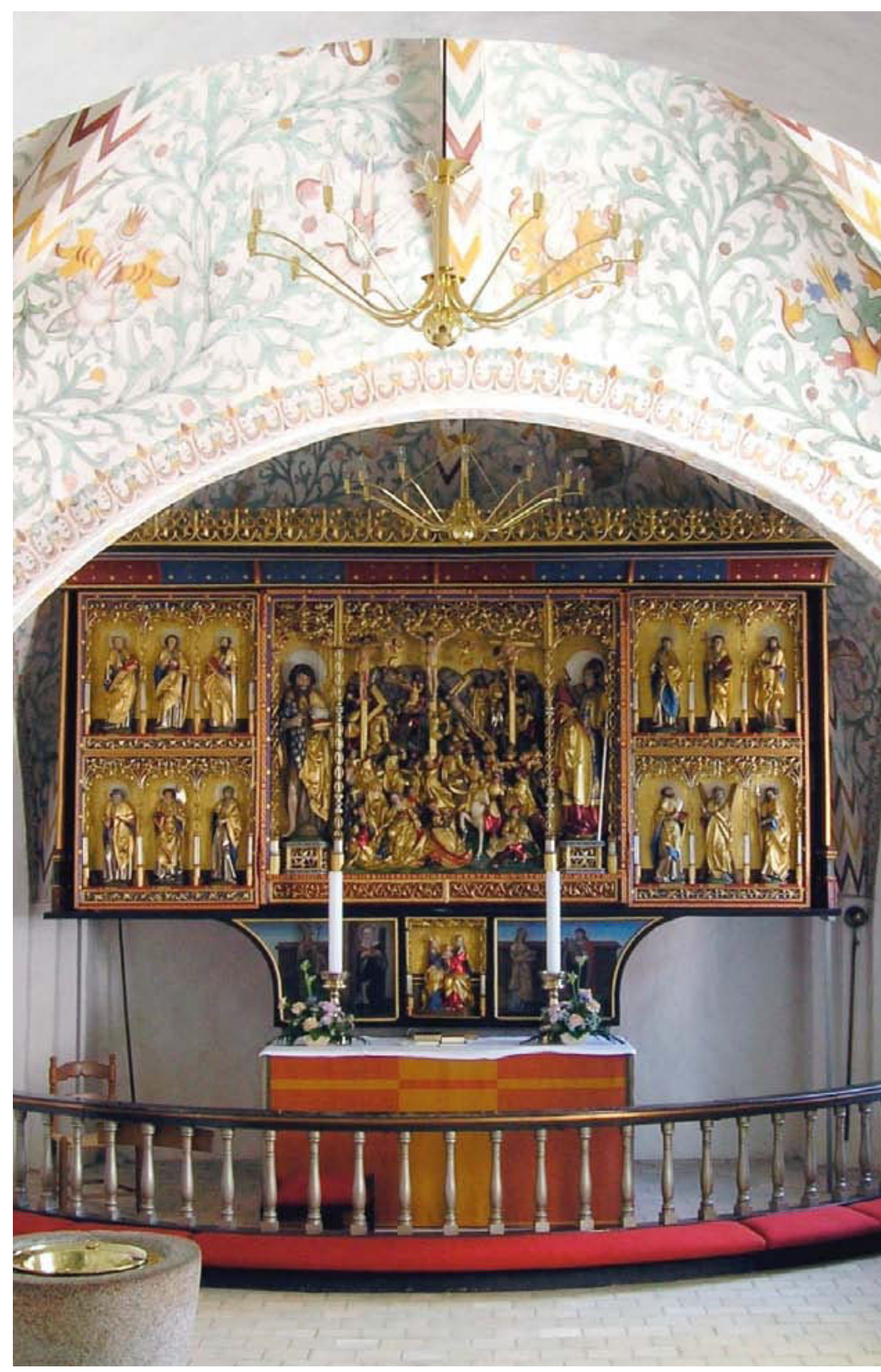

Løjttavlen som Livets Træ midt i Paradisets Have. og S. Erasmus, som i næsten legemsstore figurer flankerer den store Golgatascene på første stand (se s. 20), på tredje stand får deres martyrhistorier afbildet, herunder den krast realistiske forklaring på den vinde, S. Erasmus står med i hånden, nemlig at hans tarme blev trukket ud af ham med en brøndvinde.

Der er endnu en grund til at se nærmere på figuren af biskop Erasmus. Det er nemlig ikke utænkeligt, at den gengiver biskop Ahlefeldts portræt; under alle omstændigheder er ansigtstrækkene så individualiserede, at de må være skåret og malet efter levende model ${ }^{21}$. At Godske Ahlefeldt med andre ord gerne så sig og sit aktuelle budskab om standhaftighed i kirkestriden jævnført med martyrbispen under den romerske kejser Diokletians kristenforfølgelser i begyndelsen af 300-tallet.

At det netop blev Løjt Kirke, der kom til at huse denne enestående rige, men også politiserende og provokerende altertavle hænger formentlig sammen med sognets geografiske placering. Løjt Sogn var det nordligste, der var underlagt bispesædet i Slesvig og dermed havde plattysk som gudstjenestesprog, mens sognene længere mod nord hørte under det forholdsvis selvstændige kollegiatskapitel i Haderslev, og havde dansk gudstjenestesprog ${ }^{22}$. Kollegiatskapitlet, der bl.a. rummede en præsteskole, skulle vise sig særdeles lydhørt over for de lutherske tanker.

Det blev som bekendt "den martianske sekt," som Ahlefeldt lidet smigrende kaldte dem, der fulgte Luther, som vandt reformationsstriden. Men som en del af Godske Ahlefeldts eftermæle står stadigt den kostelige altertavle i Løjt Kirke. Dog er tavlens tredje stand, med det manende opråb om at holde den nødvendige forandring og fornyelse inden for kirkens rammer, ikke længere i gudstjenstlig brug.

Som en sidste krølle på denne førreformationshistorie, og som en sidste mindelse om Godske Ahlefeldts italienske ungdomsår, kan den, der besøger Løjt Kirke, opleve altertavlen som en del af en totaludsmykning, idet den som et vældigt, gyldent Livets Træ vokser i en samtidig, kalkmalet, italiensk inspireret paradishave ${ }^{23}$, hvis akantusrankeslyng dækker begge korrummets hvælvinger og oprindeligt væggene tillige - samt går igen i udskåret og forgyldt form på altertavlen. 


\section{LITTERATUR}

Utrykt:

Abildgaard, Søren: Notesbøger I-XIII, 1756ff. I: Nationalmuseets Antikvarisk1756ff. I: Nationalm
Topografiske Arkiv.

Trykte:

Bibelen, København 1992.

Bobé, Louis: Slagten Ahlefeldts Historie, Bd. 3 Kjøbenhavn 1903.

Bruun, Jens: "Åben bog", Skalk 1984/5.

Bruun, Jens: "Fra Biblia Pauperum til Løjttavlen", Haderslev Stiftsbog 1995.

Bruun, Jens: "Løjt kirkes altertavle i nærbilleder", Det gamle Løjt XIX, 1996.

Bruun, Jens: Løjt Kirke i ni Ärhundreder. Aabenraa 1997.
Anun,

Bruun, Jens: "Senmiddelalderlige passionsaltertavler og den folkelige mes-
selige sioforklaring", Haderslev Stiftsbog 2000.

Bruun Jens: Den Figurrige Golgatascene. En Bruun Jens: Den Figurrige Golgatascene. En
rejse gennem kristendommens kunsthistorejse gennem kristen
rie. Højbjerg 2012.

Bruun, Jens: "Løjttavlen i tid og rum en personlig rejse", Det gamle Løjt 31,
Aabenraa 2013 .
Bruun, Jens: "Løjttavlen mellem middelalder og renæssance", Det gamle Løjt 31 Aabenraa 2013.

Bruun, Jens: "Kvinderne under Jesu kors" Kirkehistoriske Samlinger 2014

DANMARKS KIRKER Danmarks Kirker Åbenrå amt 1959, s. 1782.

Gregersen, H.V.: Reformationen i Sønderiylland. Aabenraa 1986.

LØJTTAVLEN Poul Svensson, red.: Løjttavlen. Et sønderiysk alterskab. Padborg 1983

Matthaei, Adelbert: Zur Kenntnis der mittelalterlichen Schnitzaltäre Schleswig-Holtelalterlichen Schnitzaltin
steins, Leipzig 1898.

Plathe, Sissel F. og Jens Bruun: Middelalderlige altertavler $i$ Haderslev Stift, Temaer og lige altertavler $i$ Haderslev
Katalog. Herning 2003.

Plathe, Sissel F. og Jens Bruun: Danmarks the, Sissel F. og Jens Bruun: Danmark middelalderlige Altertavler - og anden billeabrrende kirkeudsmykning af betydning for liturgien og den personlige andagt. bind, Odense 2010

Thyssen, A. Pontoppidan: Dansk Præste- og Sognehistorie X, Haderslev Stift, Århu

\section{ILLUSTRATIONER:}

Med mindre andet er nævnt, er fotografierne optaget af Jens Bruun.

\section{NOTER}

1 Den tidligste gennemgang af altertavlen er i: Matthaei, Adelbert: Zur Kenntnis der er i: Matthaei, Adelbert: Zur Kenntnis der
mittelaterlichen Schnitzaltäre SchleswigHolsteins, Leipzig 1898, s. 68-71. Den mest omfattende gennemgang er LOJTTAVLEN.

De seneste er Bruun, Jens 1997, s. 27-80 og Plathe og Bruun 2010, s. 602-605.

2 DANMARKS KIRKER, s. 1788

3 Johann Tamm(sen), bevidnet 1499 1505 og 1526, sognepræst i Løjt, død her 1526(?). I: Thyssen, A. Pontoppidan
1980, s. 409, og LØJTTAVLEN, s. 33.

1980, s. 409, og LØJTTAVLEN, s. 33.
4 Kofod-Hansen, Elisabeth: Altertavlen

historie indtil reformationen. I: LØJTTAVLEN, især s. 50-55.

5 Abildgaard, Søren: Notesbog XIb,s. 24-25.

6 Achen, Svend Tito: Danske adelsvåbener 1973, s. 307
7 I senmiddelalderen begynder personer, der har bekostet en altertavle, at blive afbildet på tavlen eller repræsenteret ved deres våbenskjold el.lign.

8 Bobé, Louis: Slægten Ahlefeldts Historie, Bd. 3 Kjøbenhavn 1903, s. 7-29. Bd. 3 Kjøbenhavn 1903, s. 7-29.
Dansk biogrisk leksikon, 3. udg. bind 1 Dansk biografisk
1979 , s. 89-90.

9 Gregersen 1986, s. 41

10 Liber breuiarius secumdum ordinarium ritus ac consuitudinem ecclesiae et dioecesi Slessuicensis. Paris 1512

11 Altertavlens staffering på første stand stammer $i$ alt væsentligt fra restaureringen i 1764, hvorimod den på anden og tredje stand er original, bortset fra enkelte retoucheringer på anden stand.

12 DANMARKS KIRKER, s. 1782.

13 LØJTTAVLEN, s. 86-87.
14 I 1450 samlede biskoppen over Brixen Stift i Sydtyrol disse fire tidlige kvindelige helgenmartyrer til gruppen quatuor virgines capitales for at fremme fromheden blandt lægfolket.

15 Markusevangeliet 6,16-28.

16 Biskop i Antiokia, led martyrdøden o. 303 under kejser Diocletians kristenforfølgelser. Beskytter de søfarende og hjælper mod mavesmerter.

$17 \mathrm{Ny}$ dansk Kunsthistorie, bind 2, København 1993, s. 11-14.

18 Elsa Kai Sass i brev til forfatteren, citeret i Bruun, Jens 1997, s. 62.

19 Johannesevangeliet 1,29.

20 Bruun, Jens: Den figurrige Golgatascene, Højbjerg 2012, s. 61-64.

21 Elsa Kai Sass i brev til forfatteren, citeret i Bruun, Jens 1997, s. 41

22 Gregersen 1986, s. 25-29.

23 Kaspersen, Søren: Kirken er en have. I: LØJTTAVLEN, s. 129-142.
Der Bischof Godske Ahlefeldt und das Altarbild in der Kirche in Loit - eine Vorreformationsgeschichte

\section{Zusammenfassung}

In diesem Artikel wird es untersucht, in welchem Maße das Altarbild aus dem Jahre 1520 in der Kirche in Loit unter Einfluß von Godske Ahlefeldt, dem letzten katholischen Bischof im Bistum Schleswig, entstand. Schriftliche Quellen über die Entstehung des Bildes gibt es nicht, deshalb lässt sich allein aus der Analyse seiner Ikonografie argumentieren. Auf folgende Verhältnisse wird hingewiesen: 1) Die Wahl der Heiligen an den Flügeln, die zusammen die starken historischen Traditionen der Kirche, Wissen und Stärke, vertreten und gleichzeitig davor warnen, die notwendige Reformation der Kirche in den eigenen kirchlichen Rahmen stattfinden zu lassen. 2) Die Wahl der S. Ursula und nicht der S. Elisabeth als eine der vier Hauptjungfrauen deutet auf eine persönliche Vorliebe hin. 3) Die Renaissance-Kennzeichen auf den Bildern des Mittelfeldes deuten auf eine Offenheit der modernen Kunst gegenüber hin, die Ahlefeldt von seinen Aufenthalten in Italien mitgebracht haben kann, ähnlich wie bei den Fresken im Chor, einem italienisch inspirierten Paradiesgarten. 4) Die Darstellung des biblischen, tyrannischen Königs Herodes im Porträt und mit dem König und Herzog Christian II, der ein Befürworter der Aufteilung der Kirche in nationale Kirchen war. 5) Das Porträt von S. Erasmus auf dem ersten Stand des Bildes erscheint individualisiert und könnte als Porträt von Ahlefeldt selbst gedacht sein. 